\title{
Efficiency Analysis of Mediterranean Container Ports
}

\section{Veysel GÖKÇEK, Yunus Emre ŞENOL}

İstanbul Teknik Üniversitesi, Denizcilik Fakültesi, Türkiye

gokcekv@itu.edu.tr; ORCID ID: https://orcid.org/0000-0002-4841-0338

senolyunusemre@gmail.com; ORCID ID: https://orcid.org/0000-0001-7592-7247

\begin{abstract}
The purpose of this paper is to evaluate the technical efficiency (productivity) of Mediterranean container ports by employing the data envelopment analysis (DEA) approach. In recent years, maritime transportation volume has been increasing with the trend of trade globalization. This tendency has positive effects on container cargo flows. Accordingly, container terminals have incessant expansions to meet this growing demand. However, before making an investment in the terminal area or handling equipment, efficiency evaluation is required to reveal optimal throughput with the present resources. As the Mediterranean Basin is an important region for container transportation, there should be studies on the efficiency of container terminals in this region. In this study, relative efficiency analysis is conducted for Mediterranean container ports which are on the list of world busiest container ports based on the year 2016 data. The findings show that subjected container terminals can increase their output by 1,47 times without expanding their inputs. Efficiency is slightly increasing from eastern through the western part of this region.
\end{abstract}

Keywords: Mediterranean Region, Container Ports, Port Efficiency, Data Envelopment Analysis.

\section{Akdeniz Konteyner Limanlarının Verimlilik Analizi}

$\ddot{O} z$

Bu çalışmanın amacl, veri zarflama metodu kullanarak, Akdeniz konteyner limanlarının teknik verimliliklerini (üretkenlik) değerlendirmektir. Son yıllarda, ticaretin küreselleşme eğilimi ile birlikte deniz taşımacılı̆̆ı hacmi artmaktadır. Bu eğilim konteyner kargo akışını da olumlu yönde etkilemektedir. Buna bağlı olarak büyüyen talebi karşılamak için konteyner terminalleri aralıksı genişlemektedir. Fakat terminal alanına veya elleçleme ekipmanına yatırım yapmadan önce, mevcut kaynaklarla optimum üretim miktarını ortaya çıkarmak için verimlilik analizi gereklidir. Akdeniz Körfezi konteyner taşımacılığı için önemli bir bölge olduğundan, bu bölge için konteyner terminallerinin etkinliği konusunda çalışmalar yapılmalıdır.Bu çalışmada, 2016 yılı verilerine göre dünyanın en yoğun konteyner limanları listesinde bulunan Akdeniz konteyner limanları için göreceli verimlilik analizi yapılmıştır.Bulgular gösteriyor ki, çalışmaya dahil edilen konteyner terminalleri girdilerini genişletmeden çıktılarını 1,47 kat artırabilir. Ayrıca verimlilik bu bölgenin doğusundan batı bölümüne doğru biraz artmaktadır.

Anahtar Kelimeler: Akdeniz Bölgesi, Konteyner Limanları, Liman Verimliliği, Veri Zarflama Analizi. 


\section{Introduction}

Importance of maritime transportation has risen with the recent trend of trade globalization. There should be worldwide integrated transportation services to meet this global demand. In this point of view, shipping lines remain their position as the backbone of the global economy[1].Besides, container transportation has increasingly come into prominence by courtesy of its various technical and economic advantages over conventional transportation modes[2]. Those benefits belong to its improved port production capabilities and the crucial interface between sea and inland transportation.

Accordingly, this global trend has also effect on Mediterranean region. Containerization has continuous growth in this region and contributes to socioeconomic developments[3].By 2021, the capacity of container terminals in Mediterranean region has a potential to increase by $63 \%$ via expansion of existing terminals and new projects[4].On the other hand, there have been environmental and localized socio-economic imbalances and increasingly complex challenges to policy, opportunities, and risks in this region [3]. Port competition in the region can provide balances, improve performance, and stabilize challenges. To create a competitive environment, measurement of port efficiency is a potential management tool[5]. It also creates a critical response for enlightening port planning and operations for regional and national aspects[6].

Considering the productivity analyzes, the data envelopment analysis (DAE) and the stochastic frontier analysis (SFA) are the most used methods for container ports [7]. SFA performs parametric testing while DEA uses the non-parametric method. Referring to the researches in the literature, many researchers have preferred to use DEA because of its capacity for handling multiple inputs and outputs with independent production function specification [8].

Port efficiency analysis covering the Mediterranean region can be found in the literature $[9 ; 10]$. However, they do not deal with container ports efficiencies based on terminals specifically. Besides, abovementioned studies are conducted with data between 1998 and 2012. An in-house productivity analysis with recently available data for container terminals will support decision makers in terms of port efficiency oriented future investment plans. Hence, they can establish appropriate competitive strategies for sustainable global trade. There are 42 ports in the region with a total of 98 container terminals. The total annual Twenty-Foot Equivalent Unit(TEU) throughput of those terminals is around 60 million in 2016[11]. When we look the Mediterranean container ports which are among the world's busiest container ports in 2016[12], total annual TEU amounts of those ports (approx. 38.5 million) constitute $64 \%$ of the total TEU throughput at all 42 ports in the region. In addition, these ports have a homogeneous distribution in this region.

Existing terminals in the South European part of the West Mediterranean hold a share of $52 \%$ of the total capacity and Levant countries are coming second with 33\%[11].Hence, container ports in the list of busiest ports are mostly in those mentioned areas[4]. In order to represent the Mediterranean region, an efficiency study is considered to be meaningful to be carried out on container ports listed in the world's top 100 container ports. Because selected busiest ports cover $74 \%$ of the total TEU throughput of those leading parts. In this context, an efficiency analysis has been conducted using DEA among 14 Mediterranean ports (28 container terminals) in the world's busiest container ports list[12].

The article is organized as follows. Section 2 is a literature review of previous 
the studies on efficiency analysis of container ports. Section 3 outlines the methodology used in the analysis, Section 4 consists of definitions of input \& output variables and Section 5 gives the results of the analysis. Final section remarks the implications and concludes the article.

\section{Literature Review}

The literature includes many studies which are related to container terminal efficiency analysis. These researches are mostly carried out on container ports in the same region such as Norway, United Kingdom, Italy, Spain, Portugal, Greece, Japan, Korea, Europe, United States, AsiaPacific, Vietnam, Mexica, India, East Africa, Black Sea and etc. [7; 13]. Among these studies, there exist two significant studies dealing with container port efficient in Mediterranean region. One applies crosssectional DEA approach by using 2008 data[10], the other one utilizes panel DEA approach with the data of 1998 - 2012[9]. Both of above-mentioned studies analyze the efficiency of container ports without dealing with their terminals specifically. Additionally, some main studies for efficiency analysis are conducted to handle European[6] and Turkish [14] container ports including only a few Mediterranean Ports. Relative productivity analysis for only Mediterranean container terminals is considered to be useful for evaluating further investments to create a competitive environment.

Traditionally, the port efficiency has been assessed by measuring cargo handling productivity. One of them is a single factor based productivity [15] while another one is based on comparing tangible condition with optimum throughput over a certain time period [16]. Moreover, there exist methods originated from the estimation of a port cost function [17] and the computing of the total factor productivity [18]. Additionally, multiple regression analysis based port performance and efficiency estimation modelsare applied in the literature [19]. However, methods based on calculations of relative efficiency with respect to productive activities are growing recently. Especially, there have been developments in non-parametric frontier methods for many fields including transportation services [20]. De Borger, 2002 [12] advocates that the frontier models are widely employed in the transportation sector, especially for productivity and efficiency analysis.

In the literature mainly two frontier methods, Data Envelopment Analysis (DEA) and Stochastic Frontier Analysis (SFA), are applied for the estimation of port productivity and performance analysis. Over the past few years, DEA becomes one of the most prominent methods to measure efficiency, with its several applications to the seaport industry $[2 ; 5 ; 7 ; 21-25]$. Furthermore, cross-sectional data seem to be more frequently used in comparison to panel data[7]. For this reason, this paper focuses on the application of DEA with cross-sectional data as a convenient systematic means to compute the relative efficiency of Mediterranean container terminals which are on the list of world's busiest container ports[12].

\section{Methodology}

DEA is known as a nonparametric method to estimate relative efficiency of a Decision-Making Unit (DMU) using various inputs and outputs of a system. A DMU is determined as efficient when any increase of an output induces any increase in at least one input or any reduction in at least one other output. Otherwise, any decrease of input causes any decrease in at least one output or any rise in at least one other input.

Formally, let $\mathrm{s}$ show the population of productive units DMU1, DMU2, ..., DMUs. Each unit produces k outputs while consuming 1 inputs. Let us write an input 
matrix $X=\left(x_{m n^{\prime}} m=1,2, \ldots ., k, n=1,2, \ldots, s\right)$ and an output matrix $Y=\left(x_{m n^{\prime}}, m=1,2, \ldots . ., l, n=1\right.$, $2, \ldots, s)$. The $\varphi$-th line (i.e. $X_{\varphi}$ and $Y_{\varphi}$ ) of related matrixes hence indicates enumerated inputs and outputs of unit $\mathrm{DMU}_{\varphi}$. Then the formula for expressing the efficiency rate of each unit may be identified as:

$$
\frac{\text { weighted sum of outputs }}{\text { weighted sum of inputs }}=\frac{\sum_{\substack{m=1 \\ l}}^{l} u_{m} y_{m q}}{\sum_{\substack{n=1 \\ n=1}}^{k} v_{n} x_{n q}}
$$

where:

$v_{n^{\prime}} n=1,2, \ldots ., k$, are weights assigned to n-th input

$u_{m^{\prime}} m=1,2, \ldots ., l$, are weights assigned to m-th output

Charnes, Cooper, and Rhodes (CCR) [26] and Banker, Charnes, and Cooper (BCC) are leading approaches among other DEA models [27]. The DEA-CCR model is based on constant returns to scale approach so that this brings the advantage of proportional scale change among observed productivities. Conversely, DEA-BCC model can be shown in a piecewise linear convex frontier on the graph by courtesy of enabling variable returns to scale.

On the other hand, DEA models can be clustered as input oriented and output oriented. Depending on the strategic actions for each specific field, the proper oriented approach is needed to be selected and applied. Occasionally, container terminals encounter building a new terminal to increase their capacity. With the development of global trade, many container ports are needed to revise their production capacity to ensure sustainability of their competitive edges. In that respect, this study employs output-oriented model to provide a comprehensive benchmark for Mediterranean container ports.

In this study, as output-oriented DEA is applied, the model seeks to maximize proportions of outputs while inputs' proportions remain stationary. Linear programming techniques are utilized for output oriented models, which has diverse constraints based on the employment of DEA-CCR or DEA-BCC. Cooper provides a mathematical explanation for various DAE models with input/output-oriented approach [20]. Scale efficiency for each DMUs is obtained from technical efficiencies, originated from the DEA-CCR and DEA-BCC and given by;

$$
S E_{l}=U_{C C R_{-}} / U_{B C C_{-} l}
$$

where $U_{C R_{-} l}$ is the technical efficiency ofl th DMU obtained by CCR

where $U_{B C C_{-} l}$ is the technical efficiency ofl th DMU obtained by BCC

When $S E_{l}=1$, the DMU is scale efficient and when $S E_{l}<1$, the DMU is scale inefficient [19]. Scale inefficient DMU can be identified as not only decreasing return to scale (DRS) but also increasing returns to scale (IRS). IRS or DRS is determined by sum of weights subject to the specification of CCR model. If this sum is less than one, DMU is observed as DRS. If this sum is greater than one, DMU is observed as IRS. Else sum of weights is equal to one, DMU is observed as a constant return to scale (CRS).

\section{Definitions of Input \& Output Variables and Data}

Reflecting realistic aspects of container port production is crucial for identifying output and input variables. Port production of a container terminal essentially depends on the efficient use of land, equipment, and labor [5]. In this study, total quay length and the terminal area are considered to delegate land criteria where the number of quay gantry cranes, yard gantry cranes and straddle carriers substitute terminal equipment parameter. Due to the unavailable information on labor data, it is not included as an input variable to prevent its potential deviation effect on results. Initial test shows that there is a large correlation between yard gantry cranes and straddle carriers at 0.88 ; thus, the number 
of straddle carriers is excluded as an input variable in the final analysis [28].

Besides, container throughput is widely accepted and definitely the most important index of port or terminal output [29]. While relatively assessing activity level, size or investment magnitude of container ports, throughput is treated as an output in almost all previous studies. Also, the production capacity of the container terminal is always presented by their annual throughout as it is suitable for analytic calculations. Final established model based on input and output variables are shown in Figure 1.

The sample comprises 14 Mediterranean container ports which are onLloyd's
List One Hundred Container Ports[12]. Subjected container ports comprise many container terminals (e.g., ALTAŞ Ambarlı container port includes Marport, Kumport, Mardaş terminals). In that respect, the sample of research includes a total of 28 terminals. This sample size was determined according to recommendations on determining the minimum sample size to estimate parameters in the model being tested [30].As a general rule used in the literature, number of DMUs should be at least two times the number of total inputs and outputs[31].

All input and output data are obtained by searching ports' official websites [32-59] and

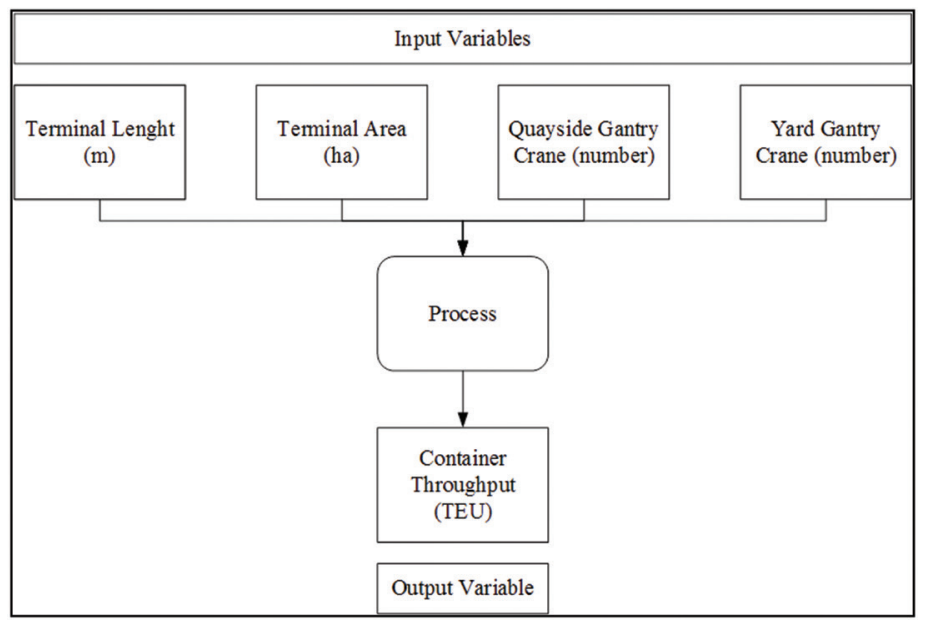

Figure 1. Diagram for Established DEA Model

Table 1. Summary Statistics for the Sample

\begin{tabular}{|l|l|l|l|l|l|}
\hline \multirow{2}{*}{ Criteria } & \multicolumn{1}{|c|}{ Output } & \multicolumn{4}{|c|}{ Inputs } \\
\cline { 2 - 6 } & $\begin{array}{l}\text { Container } \\
\text { throughput } \\
\text { (TEU) }\end{array}$ & $\begin{array}{l}\text { Terminal } \\
\text { length (m) }\end{array}$ & $\begin{array}{l}\text { Terminal } \\
\text { area (ha) }\end{array}$ & $\begin{array}{l}\text { Quayside } \\
\text { gantry } \\
\text { cranes } \\
\text { (number) }\end{array}$ & $\begin{array}{l}\text { Yard gantry } \\
\text { cranes } \\
\text { (number) }\end{array}$ \\
\hline Mean & 1375422,3 & 1438,9 & 53,2 & 11,6 & 28,5 \\
\hline SD & 953303,8 & 697,9 & 34,1 & 6,3 & 19,5 \\
\hline Minimum & 70000,0 & 526,0 & 14,0 & 3,0 & 1 \\
\hline Maximum & 3532986,0 & 3400,0 & 160,0 & 28,0 & 66 \\
\hline
\end{tabular}


e-mailing ports' authorities. Besides, relevant output data (TEU) for each container port is cross-checked via 2017 edition of the Lloyd's List One Hundred Container Ports [12]. This edition of Lloyds' List top 100 container ports uses total handled TEU in 2016 to compare container ports with each other. Gathered data serves all kind of detailed information annually from subjected ports. All essential statistics for the whole sample are summarized in Table 1.

\section{Results of Analysis}

The software MaxDEA Basic [60] is utilized to solve the established model. CCR and BCC models are employed to evaluate the efficiency of container terminals as there exists no available information on the returns to scale of the port production function. Eq. 2 - which is presented in the previous section - is applied to calculate scale efficiency of each terminal.

As indicated in Table 2, DEA-BCC model estimates average efficiency higher than the DEA-CCR model. Average values derived from BCC equal to 0,78 while it is 0,68 by BCC. Also, theindex value of 1,00 means perfect efficiency. Respectively, twelve DMUs are estimated as efficient according to DEA-BCC and there are five efficient DMUs according to DEA-CCR. The DEA-CCR model gives information purely based on technical and scale efficiency and assumes CRS. Thus, the scale of observed productivities can be proportionally up or down [61]. On the other hand, The DEA-BCC model assumes VRS to identify technical efficiency and present graphically a piecewise linear convex frontier [62]. So that DEA-BCC presented more efficient container terminal than DEA-CCR. The one-way analysis of variance (ANOVA) is employed to determine whether there exist any noticeable differences between efficiency values derived from DEA-BCC and DEA-CCR analyses. Results show that the efficiency rankings estimated by these two different models are not significantly different from each other $(F=1,8)$ at the level of 0,05 (sig. level =0,2).

Spearman's rank order correlation coefficient for efficiencies obtained from DEA-BCC and DEA-CCR is calculated as 0,83 at the significant level of 0,01 . The positive and high Spearman's rank order correlation coefficient shows that those two analyses have similar efficiency rankings. A combination of ANOVA and Spearman's rank order correlation coefficient indicates that both models bring similar efficiency evaluations and the same pattern across DMUs.

The average efficiency of container terminals obtained by employing the DEACCR model is calculated as 0,68 . As it is seen, the related terminals can averagely boost their outputs to $1,47(=1 / 0,68)$ times more efficient when the inputs are same. Empirical results indicate that there exists a significant amount of lost in container production within this sample. However, this inference depends on the convenient production scale and approaches.

Table 2 also shows the returns to scale properties of port production for each subjected terminals. Returns to scale phenomenon can be increasing, decreasing or constant. For example, it is considered to be increasing when a proportional increase in all the inputs leads to a more proportional increase in at least one output. The proportional increase of inputs are symbolized by $\gamma$ and a proportional increase of outputs are presented by $\sigma$. When $\sigma$ value is greater than $\gamma$ value, production functioning of the terminal is considered as increasing returns to scale (IRS) and if $\sigma<\gamma$, decreasing returns to scale (DRS). In case of equality $(\sigma=\gamma)$, there exists a CRS. Among the 28 terminals, 5 of them exhibit CRS, 7 of them exhibit IRS, and 16 of them have DRS.

Container ports can be classified as large or small size, based on if the output is below or above of the average throughput. 
According to this separation, large container terminals (classified as having annual container throughput of more than 1,4 million TEU), pretend as a combination of DRS (11) and CRS (5). On the other hand, small size terminals (classified as having annual container throughput of less than 1,4 million TEU) pretend as a combination of DRS (5) and IRS (7). This implies that large ports require heavy investments and advanced equipment to raise the technical efficiency while ports with lower throughput levels require a minimum scale of investments. Large ports encounter physical constraints and potential limits for further growth. Conversely, small ports do not encounter any difficulty against large ports in order to be capable of finding out capital resources for infrastructure investment.

In Figure 2, the relationship between efficiency rankings (between 0 to 1 ) and production scales (TEU) is plotted. It indicates that larger scale of production leads higher efficiency scores. Furthermore, the average technical efficiency of large ports based on both CRS and VRS models $(0,85: 0,91)$ are higher than the average technical efficiency of small ports $(0,45: 0,60)$. One can infer from this tendency that production scale directly affects the efficiency of a terminal.

Figure 3 shows the average efficiency and total annual throughput of container terminals under study located in different regions of Mediterranean. While Malta is the most efficient based on CRS model, Morocco and Portugal have higher efficiency than the other countries based on VRS model. Besides, Israel is the lowest one based on both CRS and VRS models. Also, one can infer from the figure that productivity scores are noticeably increasing while moving from eastern part through the western part of Mediterranean. There should be an important caution to overview this result that all container terminals were not included in the sample due to the concept of research and data inaccessibility. Thus our sample size may lead to small negative or positive deviation on the results. However, this finding is fascinating that regional characteristics would influence the level of efficiency and comparative competency.

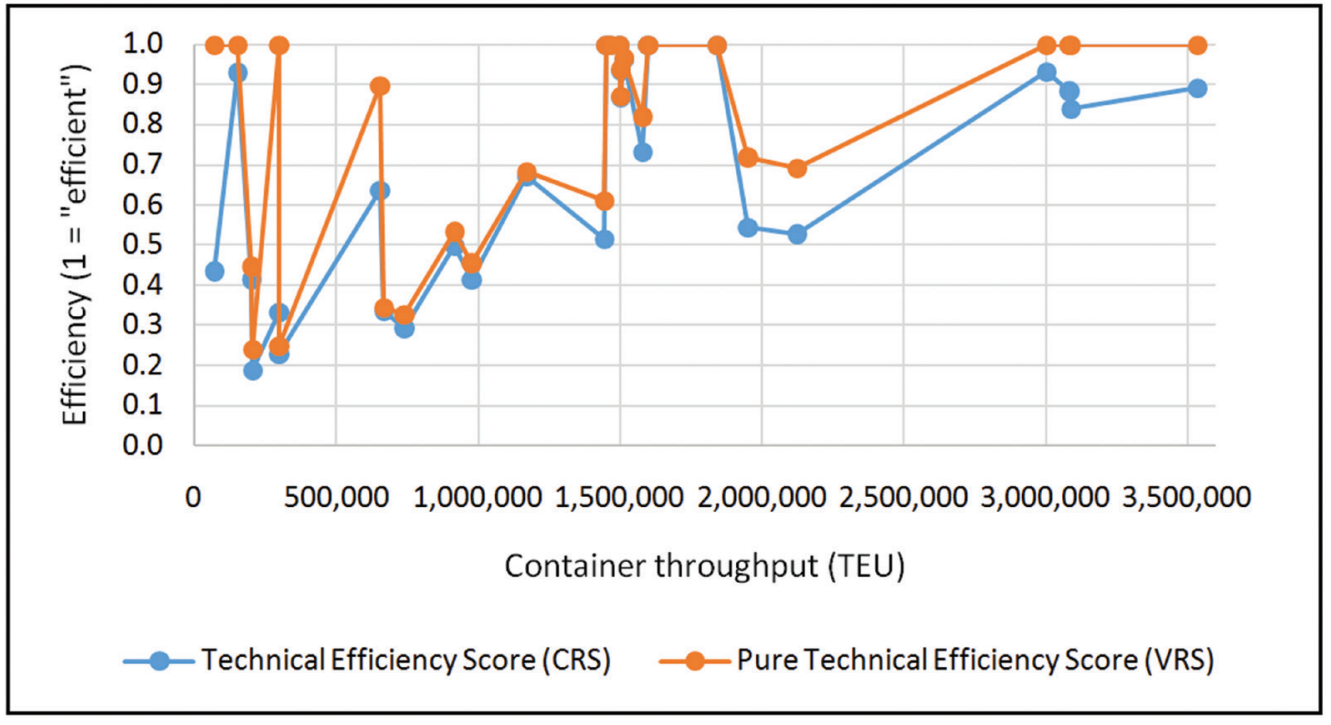

Figure 2. The Relationship between Efficiency Score and Production Scale (TEU) 
Table 2. DEA-CCR and DEA-BCC Models Based Terminal Efficiencies

\begin{tabular}{|c|c|c|c|c|c|c|}
\hline Country & Port & Terminal & $\begin{array}{l}\text { DEA- } \\
\text { CCR }\end{array}$ & $\begin{array}{l}\text { DEA- } \\
\text { BCC }\end{array}$ & $\begin{array}{l}\text { Scale } \\
\text { efficiency }\end{array}$ & $\begin{array}{l}\text { Returns to } \\
\text { scale }\end{array}$ \\
\hline \multirow{4}{*}{ Egypt } & \multirow{2}{*}{ Port Said } & AQCT $^{a}$ & 0,50 & 0,53 & 0,94 & Decreasing \\
\hline & & Suez Canal Container Terminal & 0,53 & 0,69 & 0,76 & Decreasing \\
\hline & \multirow{2}{*}{ Alexandria } & $\mathrm{ACCHT}^{\mathrm{b}}$ & 0,41 & 0,45 & 0,91 & Decreasing \\
\hline & & AICT $^{\mathrm{c}}$ & 0,64 & 0,90 & 0,71 & Increasing \\
\hline \multirow[t]{2}{*}{ Greece } & \multirow[t]{2}{*}{ Piraeus } & $\begin{array}{l}\text { Piraeus Container Terminal } \\
\text { (PCT) }\end{array}$ & 0,89 & 1,00 & 0,89 & Decreasing \\
\hline & & Piraeus Port Authority (PPA) & 0,19 & 0,24 & 0,78 & Increasing \\
\hline Israel & Ashdod & Ashdod Port Company Ltd & 0,52 & 0,61 & 0,84 & Decreasing \\
\hline \multirow{6}{*}{ Italy } & \multirow{5}{*}{ Genova } & $\begin{array}{l}\text { Genoa Port Terminal (Spinelli } \\
\text { Group) }\end{array}$ & 0,93 & 1,00 & 0,93 & Increasing \\
\hline & & Messina Terminal & 0,41 & 0,45 & 0,93 & Increasing \\
\hline & & PSA Voltri-Prà & 0,73 & 0,82 & 0,90 & Decreasing \\
\hline & & $\begin{array}{l}\text { Southern European Container } \\
\text { Hub }\end{array}$ & 0,33 & 1,00 & 0,33 & Increasing \\
\hline & & $\begin{array}{l}\text { Terminal San Giorgio (Gavio } \\
\text { group) }\end{array}$ & 0,43 & 1,00 & 0,43 & Increasing \\
\hline & GioiaTauro & MCT $^{d}$ & 0,84 & 1,00 & 0,84 & Decreasing \\
\hline Malta & Marsaxlokk & $\begin{array}{l}\text { Marsaxlokk Container } \\
\text { Terminals }\end{array}$ & 0,88 & 1,00 & 0,88 & Decreasing \\
\hline \multirow[t]{2}{*}{ Morocco } & \multirow{2}{*}{ Tanger Med } & APM Terminals Tangier & 0,94 & 0,94 & 1,00 & Decreasing \\
\hline & & EurogateTanger & 1,00 & 1,00 & 1,00 & Constant \\
\hline Portugal & Sines & Terminal XXI & 0,97 & 0,97 & 1,00 & Decreasing \\
\hline \multirow{7}{*}{ Spain } & \multirow[b]{2}{*}{ Algeciras } & Algeciras APM Terminals & 0,93 & 1,00 & 0,93 & Decreasing \\
\hline & & $\begin{array}{l}\text { Total Terminal International } \\
\text { Algeciras }\end{array}$ & 0,87 & 0,87 & 1,00 & Decreasing \\
\hline & \multirow{2}{*}{ Barcelona } & APM Terminals Barcelona & 0,29 & 0,33 & 0,89 & Decreasing \\
\hline & & BEST $^{\mathrm{e}}$ & 1,00 & 1,00 & 1,00 & Constant \\
\hline & \multirow{3}{*}{ Valencia } & APM Terminals Valencia & 0,67 & 0,68 & 0,98 & Decreasing \\
\hline & & MSC Terminal Valencia & 1,00 & 1,00 & 1,00 & Constant \\
\hline & & $\begin{array}{l}\text { Noatum Container Terminal } \\
\text { Valencia }\end{array}$ & 0,55 & 0,72 & 0,76 & Decreasing \\
\hline \multirow{4}{*}{ Turkey } & \multirow{3}{*}{ Ambarlı } & Mardaş & 0,23 & 0,25 & 0,92 & Increasing \\
\hline & & Marport & 1,00 & 1,00 & 1,00 & Constant \\
\hline & & Kumport & 0,34 & 0,35 & 0,97 & Decreasing \\
\hline & Mersin & Mersin International Port & 1,00 & 1,00 & 1,00 & Constant \\
\hline \multicolumn{7}{|c|}{ 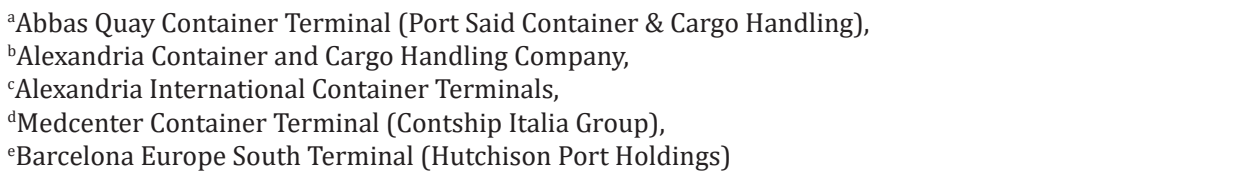 } \\
\hline
\end{tabular}




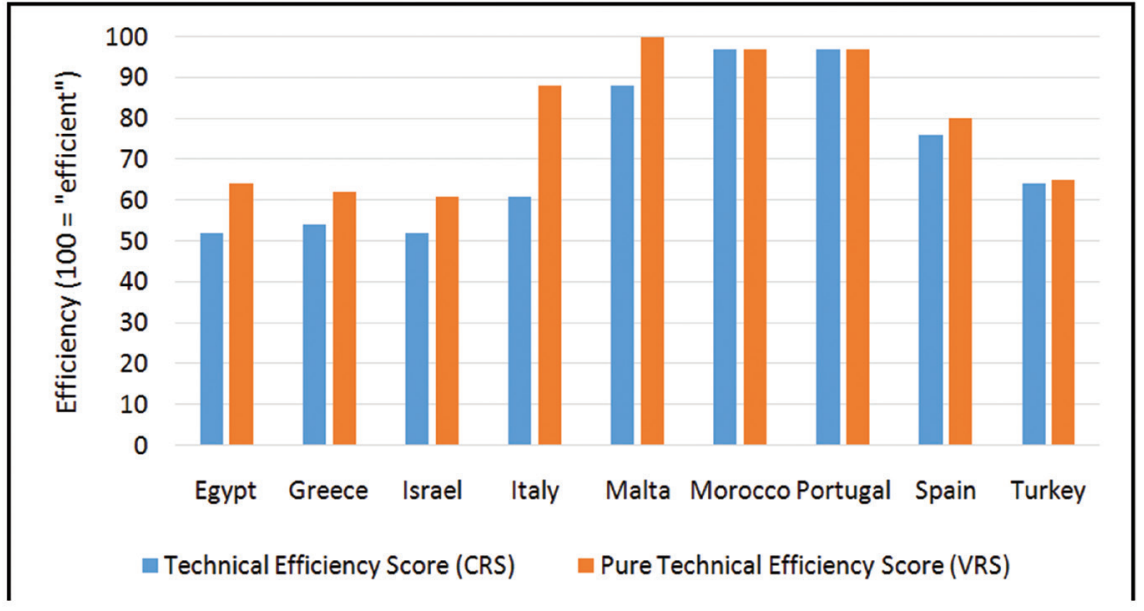

Figure 3. Productivity Comparison Based on Average Efficiency Scores of Countries' Container Terminals

\section{Conclusion}

In this paper, DEA analysis is employed to estimate the relative efficiency of Mediterranean's leading container ports which are on the list of the world's top 100 busiest container ports. For this purpose, basics of DEA were explained and input and output variables are defined through the container terminal production characteristics. Data based on 2016 statistics are collected from 28 leading container terminals across 9 Mediterranean countries to calculate individual efficiency scores for each terminal.

The average efficiency of those container terminals is calculated as 0,68 (assuming constant returns to scale) and 0,78 (assuming variable returns to scale). Generally, there is significant inefficiency in Mediterranean basin. In other words, these resultsshow that terminals in this region can improve the level of their output by up to 1,47 times while using the same inputs.

It has been also found that majority of the mentioned container terminals incline to DRS, while some container terminals display CRS and IRS characteristic. Also, most of the container terminals with larger production scales are in conjunction with higher efficiency values. These results indicate that decision-makers who have atendency to make an investment on large container ports in Mediterranean region should be careful and aware of terminals' resistance to enhancing their production scale. On the other hand, terminals which have small throughput encounter fewer difficulties, have more potential to grow and produce fewer risks than large ports.

Furthermore, it has been found in this research that container terminals in the western part of Mediterranean have higher efficiency than eastern ones. From east to west, productivity scores are slightly increasing. These findings are interesting that regional characteristics and geographical position would influence the level of efficiency and comparative competency. But there should be more detailed research to test these findings due to aforementioned reasons.

\section{References}

[1] UNCTAD. (2013). Recent developments and trends in international maritime transport affecting trade of developing countries. Paper presented at the United Nations Conference on Trade and Development, Geneva.

[2] Chang, S. M., Wang, J. S., Yu, M. M., Shang, K. C., Lin, S. H., \& Hsiao, B. (2015). An application of centralized 
data envelopment analysis in resource allocation in container terminal operations. Maritime Policy \& Management, 42(8), 776-788. doi:10.1 080/03088839.2015.1037373

[3] Medda, F., \& Carbonaro, G. (2007). Growth of container seaborne traffic in the Mediterranean basin: Outlook and policy implications for port development. Transport Reviews, 27(5), 573-587. doi:10.1080/01441640701322677

[4] Dynamar, B. V. (2013). Container Throughout \& Terminal Capacity in the Mediterranean. Retrieved from

[5] Tongzon, J. (2001). Efficiency measurement of selected Australian and other international ports using data envelopment analysis. Transportation Research Part a-Policy and Practice, 35(2), 107-122. doi:Doi 10.1016/S0965-8564(99)00049-X

[6] Cullinane, K. P., \& Wang, T.-F. (2006). The efficiency of European container ports: A cross-sectional data envelopment analysis. International Journal of Logistics: Research and Applications, 9(1), 19-31.

[7] Schøyen, H., \& Odeck, J. (2013). The technical efficiency of Norwegian container ports: A comparison to some Nordic and UK container ports using Data Envelopment Analysis (DEA). Maritime Economics \& Logistics, 15(2), 197-221.

[8] De Oliveira, G. F., \& Cariou, P. (2011). A DEA study of the efficiency of 122 iron ore and coal ports and of 15/17 countries in 2005. Maritime Policy \& Management, 38(7), 727-743.

[9] Elsayeh, M.-E. (2015). The Impact of Port Technical Efficiency on Mediterranean Container Port Competitiveness. University of Huddersfield,
[10] Polyzos, S., \& Niavis, S. (2013). Evaluating port efficiency in the Mediterranean. International Journal of Data Analysis Techniques and Strategies 7, 5(1), 84-100.

[11] TheWorldBankGroup. (2017). Container port traffic (TEU: 20 foot equivalent units). Retrieved from https://data.worldbank.org/ indicator/IS.SHP.GOOD.TU, Access Year 2017.

[12] LLOYD'sLIST. (2017). Top 100 Container Ports 2017. Retrieved from https://maritimeintelligence.informa. com/content/top-100-ports

[13] ATEŞ, A., ESMER, S., ÇAKIR, E., \& BALCI, K. (2013). Karadeniz konteyner terminallerinin göreceli etkinlik analizi. Dokuz Eylül Üniversitesi Denizcilik Fakültesi Dergisi, 5(1).

[14] Ateş, A., \& Esmer, S. (2014). Farklı Yöntemler ile Türk Konteyner Limanlarının Verimliliği. Verimlilik Dergisi, 1, 61-76.

[15] De Monie, G. (1987). Measuring and evaluating port performance and productivity. UNCTAD Monograph on Port Management. Retrieved from

[16] Talley, W. K. (1988). Optimum throughput and performance evaluation of marine terminals. Maritime Policy \& Management, 15(4), 327-331.

[17] Neufville, R. D., \& Tsunokawa, K. (1981). Productivity and returns to scale of container ports. Maritime Policy and Management, 8(2), 121-129.

[18] Kim, M., \& Sachish, A. (1986). The structure of production, technical change and productivity in a port. The Journal of Industrial Economics, 209223.

[19] Tongzon, J. L. (1995). Determinants of port performance and efficiency. Transportation Research Part A: Policy and Practice, 29(3), 245-252. 
[20] Holvad, T. (2001). An Analysis of Efficiency Patterns for A Sample of Norwegian Bus Companies. Retrieved from

[21] Barros, C. P. (2006). A benchmark analysis of Italian seaports using data envelopment analysis. Maritime Economics \& Logistics, 8(4), 347-365.

[22] Rios, L. R., \& Maçada, A. C. G. (2006). Analysing the relative efficiency of container terminals of Mercosur using DEA. Maritime Economics \& Logistics, 8(4), 331-346.

[23] Tongzon, J., \& Heng, W. (2005). Port privatization, efficiency and competitiveness: Some empirical evidence from container ports (terminals). Transportation Research Part A: Policy and Practice, 39(5), 405424.

[24] Turner, H., Windle, R., \& Dresner, M. (2004). North American containerport productivity: 19841997. Transportation Research Part E: Logistics and Transportation Review, 40(4), 339-356.

[25] Cullinane, K., \& Wang, T. (2010). The efficiency analysis of container port production using DEA panel data approaches. OR spectrum, 32(3), 717738.

[26] Charnes, A., Cooper, W. W., \& Rhodes, E. (1978). Measuring the efficiency of decision making units. European journal of operational research, 2(6), 429-444.

[27] Banker, R. D., Charnes, A., \& Cooper, W. W. (1984). Some models for estimating technical and scale inefficiencies in data envelopment analysis. Management science, 30(9), 1078-1092.

[28] Jenkins, L., \& Anderson, M. (2003). A multivariate statistical approach to reducing the number of variables in data envelopment analysis. European journal of operational research, 147(1), 51-61.
[29] Brooks, M. R., \& Cullinane, K. (2006). Devolution, port governance and port performance (Vol. 17): Elsevier.

[30] Zhang, Y., \& Bartels, R. (1998). The effect of sample size on the mean efficiency in DEA with an application to electricity distribution in Australia, Sweden and New Zealand. Journal of productivity analysis, 9(3), 187-204.

[31] Lin, L., \& Tseng, C. (2007). Operational performance evaluation of major container ports in the Asia-Pacific region. Maritime Policy \& Management, 34(6), 535-551.

[32] Suez Canal Container Terminal. Retrieved from https://scct.com.eg/, Access Year 2016.

[33] Alexandria Container and Cargo Handling Company. Retrieved from http://www.alexcont.com/, Access Year 2016.

[34] Alexandria International Container Terminals. Retrieved from http:// www.aict.com.eg/, Access Year 2016.

[35] Port Said Container \& Cargo Handling. Retrieved from http://www.pscchc. com/, Access Year 2016.

[36] Piraeus Container Terminal. Retrieved from http://www.pct.com.gr/, Access Year 2016.

[37] Piraeus Port Authority. Retrieved from http://www.olp.gr/en, Access Year 2016.

[38] Ashdod Port Company. Retrieved from https://www.ashdodport.co.il/ english/pages/homepage.aspx, Access Year 2016.

[39] Genoa Port Terminal. Retrieved from http://www.gruppospinelli.com/ index.php/en/, Access Year 2016.

[40] Messina Terminal. Retrieved from http://www.imterminal.it/index en.html, Access Year 2016.

[41] PSA Voltri-Prà. Retrieved from https:// www.portsofgenoa.com/en, Access Year 2016. 
[42] Southern European Container Hub. Retrieved from https://www. portsofgenoa.com/en, Access Year 2016.

[43] Terminal San Giorgio. Retrieved from http://www.grupposcerni.it/, Access Year 2016.

[44] Medcenter Container Terminal. Retrieved from https://www. contshipitalia.com/en/subsidiaries/ medcenter-container-terminal, Access Year 2016.

[45] Marsaxlokk Container Terminals. Retrieved from http://www. maltafreeport.gov.mt/index.html, Access Year 2016.

[46] Tangier APM Terminals. Retrieved from http://www.tmpa.ma/en/, Access Year 2016.

[47] Eurogate Tanger. Retrieved from http:// www.eurogate-tanger.com/About-us/ EUROGATE-Tanger, Access Year 2016.

[48] Sines Container Terminal. Retrieved from http://www.portodesines.pt/en/, Access Year 2016.

[49] Algeciras APM Terminals. Retrieved from http://www.apba.es/en/ containers, Access Year 2016.

[50] Total Terminal International Algeciras. Retrieved from http://www.apba.es/ en/containers, Access Year 2016.

[51] Terminals, B. A. Retrieved from https:// www.tcbcn.com/web/tcb/inicio_e.htm, Access Year 2016.

[52] Barcelona Europe South Terminal. Retrieved from http://www.best.com. es/, Access Year 2016.

[53] Valencia APM Terminals. Retrieved from http://www.tcv.es/, Access Year 2016.

[54] MSC Terminal Valencia. Retrieved from https://www.msctv.es/, Access Year 2016.

[55] Noatum Container Terminal Valencia. Retrieved from http://www.noatum. com/en/noatum-ports/valencia/, Access Year 2016.
[56] Mardaș. Retrieved from http://www. mardas.com.tr, Access Year 2016.

[57] Marport. Retrieved from http://www. marport.com.tr/anasayfa.html, Access Year 2016.

[58] Kumport. Retrieved from http://www. kumport.com.tr/, Access Year 2016.

[59] Mersin International Port. Retrieved from https://en.mersinport.com.tr/, Access Year 2016.

[60] RealworldSoft. (2017). Retrieved from http://maxdea.com/MaxDEA.htm,

[61] Wang, T., \& Cullinane, K. (2015). The Efficiency of European Container Terminals and Implications for Supply Chain Management. In Port Management (pp. 253-272): Springer.

[62] Cullinane, K., Wang, T.-F., Song, D.-W., \& Ji, P. (2006). The technical efficiency of container ports: comparing data envelopment analysis and stochastic frontier analysis. Transportation Research Part A: Policy and Practice, 40(4), 354-374. 